surface of buildings, and having a very small circular opening, two or three centimetres in diameter, for the entrance and exit of the birds. The new nests, on the contrary, represent the quarter of a hollow hemiovoid, having its poles much elongated, and its three sections adhering to the walls of buildings, except above, where the entrance is formed; and this entrance, instead of being a mere rounded hole, is a long transverse fissure bounded below by a depression of the margin of the nest, and above by a projection of the building to which the nest is attached. This aperture is nine or ten centimetres in length, whilst its gape is only two centimetres.

M. Pouchet regards this alteration in the form of the nest as not only a change, but an improvement. The greater extent of the floor gives more room for the movements of the little family, the members of which will be less heaped upon one another. The long narrow aperture enables the young birds to put out their heads so as to breathe the fresh air and contemplate the world around them, whilst the access of the parent birds to the nest without displacing the young ones is rendered far more easy, and the interior of the nest is better protected from the weather.

His attention having been called to this change in the structure of the Martins' nests, M. Pouchet set to work to examine with a glass the nests in position in various parts of Rouen. He found that upon the old churches of the centre of the town many of the nests presented the old construction, being either old nests repaired and made fit for use, or the work of conservative architects who still stuck to the old plan: the former appeared to M. Pouchet to be the most probable supposition. Mixed with these were other nests of the new form. Along the new streets of Rouen, on the other hand, all the nests were built after the new fashion.-Comptes Rendus, March 7, 1870, tome lxx. pp. 492-496.

\title{
Character of a new Species of Crossoptilon.
}

By the Abbé Armand David.

M. Milne-Edwards has communicated to the Academy of Sciences the following diagnosis of a Crossoptiton, extracted from a letter of M. A. David, dated Sse-Tchuan, December 18, 1869. The species is named $C$.corulescens:-

"Same dimensions and form as $C$. auritum; feet red; bill light red, marked with brown towards the tip; iris reddish nut-brown; head like that of the species from Pekin, with the elongated feathers of the ears a little more developed; general colour of the plumage a uniform and very fine dark-bluish slate-colour, except that the ends of the large feathers of the tail are black and shining, with green and violet reflections; the three or four small lateral feathers are white at their basal portion or entirely, according to age; the large quill-feathers of the wings also are olive-coloured; and the black velvety feathers of the top of the head are separated from the slatecoloured feathers of the neck by a small white streak."-Comptes Rendus, March 7, 1870, tome lxx. p. 538. 


\section{$2 \mathrm{BHL}$ Biodiversity Heritage Library}

David, Armand. 1870. "Character of a new species of Crossoptilon." The Annals and magazine of natural history; zoology, botany, and geology 5, 308-308. https://doi.org/10.1080/00222937008696164.

View This Item Online: https://www.biodiversitylibrary.org/item/63493

DOI: https://doi.org/10.1080/00222937008696164

Permalink: https://www.biodiversitylibrary.org/partpdf/59497.

\section{Holding Institution}

University of Toronto - Gerstein Science Information Centre

\section{Sponsored by}

University of Toronto

\section{Copyright \& Reuse}

Copyright Status: NOT_IN_COPYRIGHT

This document was created from content at the Biodiversity Heritage Library, the world's largest open access digital library for biodiversity literature and archives. Visit BHL at https://www.biodiversitylibrary.org. 